\title{
Democratisation without Coercion: Parliamentary Bodies as Democracy Promoters in the Mediterranean
}

\author{
BY Mark A. Harwood * \\ Institute for European Studies, University of Malta, Tal-Qroqq MSD2010, Malta \\ * Correspondence: mark.harwood@um.edu.mt
}

In an attempt to decentre the debate of democracy promotion in the Mediterranean, this article applies social constructivism to an analysis of the work undertaken by two International Parliamentary Bodies in the Mediterranean. With a focus on the European Parliament and the Parliamentary Assembly of the Mediterranean, we analyse how effective their role can be without coercion and move on to discuss whether newly formed democratic parliaments, as in Tunisia, may represent a more legitimate and viable source of parliamentary-driven democracy promotion.

Keywords: European Parliament, International Parliamentary Institutions, Parliamentary Assembly of the Mediterranean, Tunisian Parliament, Social constructivism

\section{Introduction}

As democratisation efforts increased after the beginning of the Arab Spring in 2011, the work of the international community to influence change in the region became a major topic of academic debate. Part of that interest has focused on the role of parliamentary bodies, both domestic and international. However, the proliferation of International Parliamentary Institutions (IPIs) in the region raises the question as to whether they have had any actual impact. By focusing on the activities of the European Parliament and the Parliamentary Assembly of the Mediterranean, this article will analyse the contribution of IPIs to democracy promotion in the region and discuss the potential of national parliaments to represent more legitimate sources for change in North Africa by analysing the Tunisian parliament's role in the country's democratic transition. 


\section{The Arab Spring and Europe's response}

The Arab Spring or Awakening began in Tunisia in December 2010 and quickly spread across North Africa and the Middle East. Within months, established rulers in Tunisia, Egypt, Libya and Yemen had been forced from power while Bahrain and Syria faced serious civil unrest. Of these countries, Tunisia is believed to have fared best, having transitioned into a semi-presidential, if not flawed, representative democracy. The other states fared less well and either descended into civil war (Libya and Syria), saw the entrenchment of old regimes through partial constitutional reforms (Morocco) or saw the reinstatement of old patterns of authoritarian control (Egypt) though political unrest in Sudan from December 2018 and in Algeria from February 2019 have led some to question whether we are seeing a new Arab Spring (Alterman, 2019).

The European Union has a long history of cooperation with the Mediterranean, in particular with the Maghreb countries. From 1972, the European community tried to establish a coherent approach to the region with the launch of the Global Mediterranean Policy and France, Spain and (to a lesser degree) Italy have consistently pushed for European Community/Union policies for the Mediterranean over the years. That push culminated in the 1995 EuroMediterranean Partnership, the 2003 European Neighbourhood Policy (ENP) and the 2008 Union for the Mediterranean though none of these initiatives met the expectations with which they were originally launched. The European Union is often hampered in the region by the fact that its competences are limited outside the area of trade while its foreign and security policy necessitates unanimity; the need for compromise between its Member States has often meant that concerns regarding migration, terrorism or energy supplies led the Union to favour stable regimes in the Mediterranean over accountable ones.

The European Union's initial response to the Arab Spring focused primarily on its diplomatic and trade efforts with no military involvement other than on a unilateral basis or under the North Atlantic Treaty Organisation with 10 EU countries eventually participating in 'Unified Protector', led by France and the UK. In the area of trade and diplomacy, the EU's potential was more pronounced and after the ousting of the regimes in Tunisia and Egypt, the EU, through the High Representative, promised enhanced economic support in return for constitutional reforms and free elections. Soon after the EU issued a revamped Neighbourhood Policy for the region promising the $3 \mathrm{Ms}$, namely 'money, mobility and markets' on condition that partner countries would deliver on building and consolidating democratic political systems.

It is debatable as to what degree the EU's policy in the region has contributed to political transformation, especially as the political outcomes of the Arab Spring have varied so widely while being underscored by the same EU approach. 
Some argue that the EU's policy in the region has been dominated by two simultaneously present discourses, namely the cooperative security discourse, with an emphasis on common security challenges, and the liberal reform discourse with the focus on democratisation and liberalisation as a way of solving regional problems and enhancing EU security (Malmvig, 2004). In addition to this consideration, 'another common criticism is the narrow conception of democracy, defined as "fuzzy liberalism” used by EU actors' (Gomez Isa and Munoz Nogal, 2016, p. 16) with Jonasson (2013) arguing that this reveals a liberal bias orientated towards market economics, individual rights and prioritising funds to support civil society.

The aim of this article is to analyse the role played by parliaments in the democratisation process in the region. We begin by discussing democracy promotion and the potential for parliaments to play a role before analysing the various parliamentary bodies active in the region. We then move on to analyse the actual work of two parliamentary bodies in more detail, namely the European Parliament and the Parliamentary Assembly of the Mediterranean. The latter represents one of the two intra-regional parliamentary bodies in the Mediterranean while the former, the European Parliament, has been the most conspicuous and consistent IPI actor in terms of democratic promotion in the Mediterranean both before and after the 2011 Arab Spring. From here, we then analyse the potential represented by the emerging democratic parliaments in the region, with a special focus on Tunisia, to represent agents of democratisation with greater regional legitimacy.

\section{Parliaments and democratisation}

Grugel (2007) talks about democratisation as sitting at the intersection of domestic and global and involves two stages, transition and consolidation. 'Democratisation is a process of identity transformation during which the norms of "popular control and equality" gradually become embedded in states and societies' (Grugel, 2007, p. 172). At its core, it requires a shift in the identity of elites as they accept a relative loss of social and political authority. For Flockhart, the 'focus is on the external influences on democratisation through the promotion/socialisation of a specific set espousing a commitment to a "Western" conception of liberal democracy, human rights, the rule of law and a market economy, and how the results of the processes of change at the domestic level "loop back" to the external level with structural change' (Flockhart, 2005, p. 6). In this way, much of the debate on democratisation is now firmly embedded in social constructivism.

Social constructivists concur that socialisation takes place best after a critical juncture or a destabilizing ideational shock which undermines established 
norms, leaving the agents in a state of 'normlessness' but that new norms cannot be expected to land freely and should be promoted by someone (Checkel, 1999; Marcussen, 2000). In social constructivism, norms and socialisation play an important role in identity construction. To encourage socialisation, two different strategies are highlighted in the literature, namely social influence and persuasion. In terms of influence, the emphasis is upon the distribution of social rewards and punishments as a means of influencing pronorm behaviour. In terms of persuasion, the emphasis here is upon the use of material or mental coercion to bring about change. However, the above depends on the actor being socialised as identifying with the higher group, which might not be the case with the Mediterranean states (Flockhart, 2005, p. 49). Further to this, the idea is also that the norm should land deeply, hence the importance of the receiving group and their link with the wider population in the receiving state, so as to ensure that norm transfer does not remain an elite exercise. Ultimately, Flockhart develops a model which hinges on whether the receiving state aspires to western ideals and what form of institutions it has, namely liberal democratic government. If there are limited opportunities to socialise, then norm transfer cannot land (Flockhart, 2005, p. 58). With the emphasis in this article on the role of external actors in the region, the 'outside' dimension is key for understanding the role of IPIs in the region. Ultimately, 'external norms stand more chance of taking root when they converge with already-established cultural practices' (Acharya, 2004 as quoted in Grugel, 2007, p. 174). This sentiment echoes the opinion of Jonasson (2013) who argues that there must be three vital elements for democracy promotion, namely orientation towards the project of democracy promotion on the part of the target country, local ownership of the project and dialogue between the democracy promotor and different segments of the target state.

In terms of the latter, a key variable is how the external norms land in the agent country, including access to the country and establishment of winning coalitions. In particular, Flockhart talks about the standing of social groups and how our aspiration to join them may determine our openness to the norms they are representing. As will be discussed, this has been a challenge for external actors like the EU with Ross Smith measuring the effectiveness of the Union in influencing democratisation by focusing on its efforts in terms of legitimacy (does the EU prioritise normative goals over economic ones), identification (does the target group identify with EU ideals) and resonance (were the two sides on the same page normatively) (Ross Smith, 2011, p. 398). Ultimately, this reflects the reality that the EU itself recognises, namely that the third country must want democracy: 'The last ENP review admitted ... that the effectiveness of this approach depended on the readiness of third country governments to cooperate' (Zamfir et al., 2016). 
Beyond the EU, with the growing interest in non-traditional inter-state diplomacy, the academic literature has also seen an increase in interest regarding the work of parliaments and parliamentary bodies in diplomacy. This reflects the fact that these bodies have engaged in a wide range of international activities including communication, reporting, policy analysis and some forms of representation (Cofelice and Stavridis, 2017, p. 4). Parliamentary diplomacy means 'the activities of parliamentarians that are aimed at increasing "mutual understanding between countries, to assist each other in improving the control of governments and the representation of a people"', (Weisglas and de Boer, 2007, p. 94; Fiott, 2015, p. 2). In defining parliamentary diplomacy, it is more than just parliamentary cooperation with the literature referring to the fact that parliamentarians do not always concur with their government's stated position, giving them 'a margin of flexibility that is denied to diplomats' (Beetham, 2006, p. 6); Reinprecht and Levin define this as parliamentarians being able to speak more plainly because they wield less power than governments, which also makes them more flexible and less likely to harm inter-state relations (Reinprecht and Levin, 2015, p. 9). That said, others argue that it can result in parliamentary tourism with a lack of continuity due to the brevity in political career of some parliamentarians.

In analysing the work of parliaments, the literature makes reference to the functions associated with parliaments as including parliamentary legislation, listening, international exchange and training, field missions in crisis areas as well as acting as a moral tribune (Cofelice, 2016b, p. 102). However, as the discussion on social constructivism shows, it is not enough to simply initiate parliamentary diplomacy; in addition to assessing how IPIs actively engage with the region, it is central to also assess how that involvement is received and followed through into domestic consolidation of democratic principles in the receiving states. Therefore, in an attempt to decentre the debate and add to the literature, we will apply social constructivism, a principle context for understanding democracy and democratisation, as well as an increasingly popular framework for understanding the EU (Jupille et al., 2003; Risse, 2005), to the efforts of parliaments in promoting political change in North Africa since the Arab Spring.

\section{Parliamentary bodies in the Mediterranean}

Parliamentary bodies in the Mediterranean have increased significantly in the last two decades. Cofelice and Stavridis distinguish them in terms of the level of governance, from the most local to the more global (Cofelice and Stavridis, 2017, p. 8). Taking the number of chambers in the EU and Mediterranean riparian states, they calculate there are 66 parliamentary chambers in the region, not including sub-state parliaments as in Spain. Beyond the national parliaments they then list IPIs which they subdivide into five groups: 
(1) parliamentary entities with a universal or non-geographical membership as with the Inter-Parliamentary Union;

(2) parliamentary entities with membership comprising countries from the northern shore of the Mediterranean such as the European Parliament;

(3) parliamentary entities with membership comprising countries from the southern shore, such as the Pan-African Parliament;

(4) North-South Mediterranean parliamentary bodies, namely the Parliamentary Assembly of the Union for the Mediterranean (PA-UfM) and the Parliamentary Assembly of the Mediterranean (PAM); and

(5) IPIs which are not specifically Mediterranean centric, but have a strong Mediterranean dimension such as the World Hellenic Inter-Parliamentary Association.

As they note, only the fourth group truly represents an intra-regional IPI, where parliamentarians from both shores meet exclusively, a key distinction for our topic. Cofelice and Stavridis see this proliferation of parliamentary bodies in the region as reflecting the push by international organisations to expand into the region as well as an attempt for countries to 'forum shop' (Cofelice and Stavridis, 2017, p. 21). However, this proliferation of IPIs has two features that can question their utility, namely their structure and functions. In particular, they note that most of these institutions involve a plenary, a bureau and standing committees but little else while most IPIs are restricted to issuing non-binding statements with limited impact outside of the IPIs.

With our emphasis upon the role of parliamentary bodies as democratising agents in the region, we will focus on the work of IPIs from the second and fourth group as these have an exclusive or specialised regional focus, a wholly or significant membership of European delegates from democratic states as well as having, as part of their mandates, democracy promotion. To this end, we focus upon the work of the EP and PAM, both conspicuous parliamentary actors in the region.

\subsection{The Parliamentary Assembly of the Mediterranean}

The Parliamentary Assembly of the Mediterranean was established through the institutionalisation process of the Inter-parliamentary Conference on Security and Cooperation in the Mediterranean which was itself established by the InterParliamentary Union in 1992. With 27 fulltime members, it is the only Mediterranean institution with exclusive membership from the littoral countries of the Mediterranean and held its first plenary in September 2006 (Cofelice, 2016a, p. 295). 
PAM's mandate is two-fold, the first being conflict prevention, resolution and crisis management through parliamentary diplomacy. Its second is the promotion of human rights and democracy, as reaffirmed in PAM's political manifesto, The Charter of the Mediterranean, adopted in 2008, where democracy and human rights are the 'foundation stones for the actions of PAM' (Cofelice, 2016a, p. 297). The 27 national delegations are composed of a maximum of 5 members, elected or appointed by national parliaments, with each national delegation having equal voting rights. The Assembly's plenary meets once a year, but the majority of its work is undertaken by three committees dealing with: political and security-related cooperation; economic, social and environmental cooperation; and dialogue among civilisations and human rights. The Bureau ensures continuity and is based in Malta. Unlike other bodies such as the UfM-PA, PAM does not tackle issues of input legitimacy, allowing the participating states to nominate their delegates (Cofelice, 2016a, p. 298). In this way, while the UfM-PA suspended Syria after the upheavals in that country, PAM has never taken steps to suspend a member. This can bring into question PAM's stated aim of contributing to democracy but also facilitates its role of creating dialogue and respect for difference of opinion.

PAM's tools primarily centre on soft diplomacy, comprising non-binding reports, opinions, resolutions and declarations as PAM lacks an intergovernmental counterpart and therefore cannot exercise core parliamentary functions like policy making and oversight of the executive (Cofelice, 2016a, p. 299). But, through its role as 'norm entrepreneur' and with technical assistance, it is able to promote democracy while its role as moral tribune and its parliamentary diplomacy allow it to address conflict resolution and crisis management (Cofelice, 2016a, p. 299).

\subsection{The European Parliament}

The European Parliament, originally established in 1952 as the European Coal and Steel Community's Assembly, is a directly elected parliament comprising 751 members from the $28 \mathrm{EU}$ Member States, seats being allocated in proportion to each country's population size and with members sitting in 8 party groups, primarily constituted on the left/right political spectrum. With oversight of the EU's budget, legislative powers shared with the Member States (sitting in the Council of the EU) and oversight of the Commission, the EP is considered one of the most powerful parliaments in the world.

The European Parliament's role in democracy promotion takes place within the parameters of the Union's competence in this area as provided under the treaties. Since 2009, the EU has undertaken democracy promotion through a country-specific approach, stakeholder involvement and greater coherency with 
democracy and human rights being mainstreamed across all policy areas. These policies have been supported by the European Instrument for Democracy and Human Rights, as well as more specific funds for the EU's neighbours, namely the European Neighbourhood Instrument and the Neighbourhood Civil Society Facility. In addition to these funds, there are also additional funds related to development policy, the European Endowment for Democracy and the EU's Instrument contributing to Stability and Peace.

Parliament contributes to democratisation through various activities, especially as EU co-legislature in areas such as trade agreements and development policy. More specifically, it also promotes these ideals through participation in the EU's election observation missions. Complimentary to this, the EP also involves itself in election follow-up, human rights and support for parliamentary work. In terms of the latter, the EP helps parliaments outside the EU in strengthening institutional capacity (with conferences and seminars, joint training programmes and study visits). The EP also gives support in the area of mediation and dialogue. Parliament's work in this area is channelled through two principal committees, that on Foreign Affairs and the other on Development, while the Parliament's Democracy Support and Election Coordination Group provides political guidance overall.

\section{Analysis of the impact of IPIs in the region}

As outlined above, parliamentary diplomacy is normally differentiated in terms of acting as a moral tribune, parliamentary legislation, listening, international exchanges and training as well as field missions in crisis areas (Cofelice, 2016b). Through these activities, parliaments can contribute to democracy promotion and crisis management, as was the case in the Mediterranean with the EP and the PAM.

In terms of acting as a moral tribune, the EP took a coherent and active role as a moral tribune in the region, being forceful in recognising the Arab Spring as legitimate representation of the wishes of Arab societies and condemning the use of force against protestors (Cofelice, 2016b, p. 103). Also, the EP was of note in promoting the responsibility-to-protect (R2P) concept (Stavridis and Fernández Molina, 2013). ${ }^{1}$ This way, the EP is believed to have taken a clear lead, immediately expressing solidarity with the protestors, identifying with them and providing support at a time when other actors, such as the High Representative, were more cautious and advocated for stability (Reinprecht and Levin, 2015).

\footnotetext{
${ }^{1}$ The Responsibility to Protect (R2P or RtoP) is a commitment endorsed by the United Nations at the 2005 World Summit with the aim to prevent genocide, war crimes, ethnic cleansing and crimes against humanity.
} 
Subsequently, the EP maintained its support for transition, seeing the protests as a wish for popular democratisation and through the Committee on Foreign Affairs (AFET) and the Subcommittee on Human Rights (DROI), the EP issued repeated statements declaring that the demonstrations were legitimate representations of the desires of Arab societies.

In this area, PAM was less categorical as an actor, calling for the need to overcome current challenges in the region but not taking sides. This difference reflects the fact that PAM only meets once a year, meaning that it is slower to react to developments. Also, because positions need unanimity or 4/5 support, its conclusions always involve broad compromise (Cofelice, 2016b, p. 106). In terms of R2P, it took PAM until 2015 for it to include R2P in its plenary discussions and then by placing emphasis on the first pillar which focuses on governments and the need to protect their civilians. Ultimately, PAM's policy of not interfering in the composition of national delegations means that PAM does not actively act as a moral tribune.

In the area of parliamentary legislation and oversight, the EP has extensive legislative powers within the EU framework and used these in terms of the Arab Spring, drafting their own recommendations for the revamped Neighbourhood Policy and pushing for the 'more for more' principle; for the EP, the parliament was determined to reverse the ENP approach where 'securitised relationships marginalised "[European] normative principles and aspirations for Arab reform"” (Hollis, 2012, p. 94). To consolidate its monitoring function, the EP also established the Monitoring Group on the Situation in the Southern Mediterranean under the AFET with special focus on oversight of the EU's financial assistance to the region (Cofelice, 2016b, p. 108). On the other side, PAM could not undertake these functions directly other than in recommending standards as a norm entrepreneur; in some of these cases, the PAM tried to reinterpret certain rights, as it did notably with the definition of terrorism, adopted in 2009. While some countries did not participate in voting, PAM persevered and has tried in other areas to replicate this, as with forced migration and organised waste trafficking (Cofelice, 2016a, p. 231). In the same way, PAM has also tried to harmonise the legislation of Member States in the area of family law, domestic violence and strategies to combat public sector corruption, but PAM has no follow-up mechanism and this creates an institutional deficit; without follow-up mechanisms and with highly generalised reports which shy away from naming and shaming member countries, its role as a norm entrepreneur is severely hampered (Cofelice, 2016b, p. 110).

In terms of listening, where listening is defined as 'the collection and analysis of data or information or opinion from the target foreign public by an international actor', the EP was considered to have a natural strength in this area, through inter-parliamentary delegations with Middle East and North African (MENA) parliaments, joint parliamentary committees and the PA-UfM assembly 
(Cull quoted in Reinprecht and Levin, 2015, p. 11). This role of listening was complemented by ad hoc and standing committees as well as the President of the $\mathrm{EP}$, political groups and individual MEPs visiting the region. Because of its regional delegations, the EP is unique in having a track record of full-time politicians focused on and travelling to the region. In addition to the individual visits, the Monitoring Group on the Situation in the Southern Mediterranean facilitated the diffusion of information among various stakeholders including the European External Action Service and the Commission. PAM also functions in this capacity; in particular, PAM's cross-regional membership facilitates listening while its missions to various countries in the region have shown a willingness to engage in listening, though Cofelice concedes that PAM has been less successful in terms of civil society preferring to interact with national and regional representatives (Cofelice, 2016b).

In the area of international exchanges and training, both IPIs have been active. In terms of international exchanges, the EP managed these through the Office for the Promotion of Parliamentary Democracy (OPPD), which was created in 2008. Centred on the assumption that the EP was a model, the OPPD offered capacity building services, reform guidance, election monitoring follow-up, exchange of best practice, civic cultivation of online public spaces and peer-to-peer mentoring. While not restricted to the ENP countries, the programmes were rebalanced towards the MENA countries in 2011 after the Arab Spring with many of the OPPD's documents being translated into Arabic. The OPPD organised training seminars for staff, members and candidates of Southern Mediterranean parliaments with particular emphasis on female and minority representation. When the EU-Arab summit issued the Cairo Declaration in 2012, a key commitment was for the 'European Parliament and the Arab Parliament to strengthen communication' (Reinprecht and Levin, 2015, p. 22). In terms of professional exchanges, these were managed through the Young Political Leaders programme with the first Young Leaders Middle East forum being held in 2012. In terms of PAM, while it has always used training as a tool, since the Arab Spring the focus has been upon human rights and terrorism. To maximise its capacity for dialogue, PAM has also been given observatory status to other regional IPIs, such as the Maghreb Consultative Council (Cofelice, 2016b, p. 113).

In terms of field missions to crisis areas, the EP focuses primarily on election monitoring and established a small mediation unit within its Secretariat, as discussed previously. For PAM, this is a major focus. In terms of crisis management, PAM originally focused on the Middle East but turned towards North Africa with the Arab Spring. In particular, it has always supported the UN and other players in trying to resolve conflict in the region and has made three important contributions; first, financial support, to fund pilot projects in Egypt, Jordan, Morocco and Tunisia. This has been undertaken through the European Bank for 
Reconstruction and Development. Secondly, it helped with constitutional reform in Tunisia and Libya, with PAM being one of the first parliamentary delegations to visit Tunisia and to assist with the constitutional reform process. It also established a joint mission to Libya to help the country reform and established parliamentary training sessions for Libyan MPs (Cofelice, 2016a, p. 306). Thirdly, PAM has been active in Libya and Syria on humanitarian missions. Finally, PAM has also established an MP pool to help with crisis management in conflict areas and to help facilitate negotiations.

From the discussion, it can be seen that IPIs have played a significant role in the region but that more has been done in terms of crisis management than democracy promotion. Ultimately, the ability of IPIs to be effective democracy promotors is limited because they often do not have the ability to speak with legitimacy because the values being recommended are external (EP) or circumscribed because of the need for intra-regional consensus (PAM). Further to this, the ability to effect change through social influence or persuasion is limited. In terms of the EP, it has the ability to persuade through its capacity to influence EU policies in the region but heavy handed influence does not always land well; the use of social rewards or shaming is limited when the actor is external and the IPI is promoting ideals which do not resonate in the region, especially liberal values including minority rights. The PAM is also limited in this respect due to the fact that its declarations are consensus based, and it has no follow-up capacity meaning that there is no attempt to monitor the degree to which its message lands in the region. Further to this, it is important that the actor through which the normative transfer is happening, national parliamentarians in our case, are deeply embedded in the domestic political system with links to the people which then reinforces democratisation. Regretfully, national parliaments (and foreign actors like the EU) do not always enjoy popular legitimacy in the Arab states that such a relationship would necessitate. Ultimately, the IPIs are better suited for providing crisis management roles than effective democracy promotors in the region. With this assessment, the capacity for international parliamentary bodies to act as agents of change may appear limited. That said the establishment of national, democratic parliaments in the region and their role as exporters of a more ethnocentrically acceptable form of democracy may represent a more viable potential for parliaments to play a role in the region as well as representing a more promising and legitimate partner for IPIs in ensuring that any normative transfer would land in the target country with greater legitimacy.

\section{The Tunisian Parliament}

Before 2011, parliaments had little influence in Arab politics, 'Arab parliaments saw themselves as a part of their governing regimes, rather than as critical 
counterweights' (Volkel, 2017, p. 596). In the same vein, 'literature on regional parliaments in Africa is inchoate, embryonic, scarce and dispersed. This may be attributed to the little appetite that researchers may have for such regional parliamentary outfits regarded as weak and ineffective' (Stavridis and Irrera, 2015, p. 157).

There are only two parliaments in the region which can be considered within a democratic framework, namely Turkey and Tunisia, though both states are classified as only partially free and democratic. While Turkey has a longer democratic tradition, the swing towards a more presidential form of government under Erdogan as well as Tunisia's significance for the Arab Spring movement, would indicate a greater potential for parliamentary diplomacy to be played by the Tunisian parliament; 'One of the things Tunisians got right (after the revolution) was the rejection of presidentialism in favour of parliamentary democracy. Tunisians recognised the dangers of presidentialism in a country with a weak democratic tradition and historic lack of checks and balances' (Sezgin, 2015, p. 36). In fact, 'if there is any model of Muslim democracy post-Arab Spring, it is Tunisia, not Turkey' (Sezgin, 2015, p. 36).

The Tunisian constitution was adopted in 2014 after 2 years of consultation and drafting. While not always smooth, the national dialogue and the work of the National Constituent Assembly managed to broker a compromise among the various factions, in particular secularist, led by the Nidaa Tounes party, and Islamists, primarily represented by the mainstream Ennahda party. Tunisia is now classified as a unitary, semi-presidential representative democracy with the president sharing executive power with the government and having competence over defence, foreign policy and national security, power of key appointments, including that of the Grand Mufti and the head of the central bank, as well as enjoying legal immunity while in power. Beji Caid Essebsi, founder of Nidaa Tounes, was elected President in 2014 and remains in office, presidential elections due next in November 2019. The Assembly of Representatives of the People (ARP) is a unicameral parliament with 217 members, over $30 \%$ of whom are female. Bills can be proposed by the President or by the Head of Government as well as by (at least) 10 members of the house. Bills and amendments are struck down if they damage the Finance Acts' budgetary balance and ordinary laws can be passed with a simple majority (as long as this represents a minimum third of the ARP members). In the 2014 parliamentary elections, Nidaa Tounes won 85 seats and Ennahda won 69 with 13 other parties also being elected to the house. The current Prime Minister, Youssef Chahad (Nidaa Tounes), was appointed in 2016 with parliamentary elections due in October 2019. It has been noted that the 'Tunisian constitution is the first in the Arab world written outside the influence of a dictator or foreign power' (Pickard, 2014, p. 4) and that the political system created in 2014 'departs from the tradition of constitutional 
authoritarianism and, at least in its written form, could serve as a genuine guarantor of democracy' (Pickard, 2014, p. 137). In this way, the Tunisian political system is an important phenomena in the region, a transitioning political system underscored by broad human rights that might not fully mirror European values but which are ground-breaking for the region and primarily self-referencing, giving a greater potential for deep democratisation in a social constructivist sense because the values are formed in a North African framework. Ultimately, 'Tunisia's constitution ... is rightly regarded as a milestone in North Africa's political history, and the region's most progressive and democratic constitution' (Gallien and Werenfels, 2019, p. 2), effectively limiting the role of the military, guaranteeing equality between the sexes, ensuring judicial independence as well as the separation of religion and politics.

However, while Tunisia has fared better than other countries in the region after the Arab Spring, it has not been without its problems. Terrorist attacks in 2015 brought about the effective collapse of the tourism industry with public debt increasing to $70 \%$ of gross domestic product and foreign currency reserves becoming so low that the IMF was forced to issue a financing facility in 2016 and inflation still continues to be a problem. From January 2018, in reaction to new financing laws which increased taxes, demonstrations increasingly turned violent and reflected a growing tide of unhappiness at the country's economic and political situation; in particular, that attempts at reforms seemed hampered by entrenched interests (primarily the unions, corrupt elites and leaders of the informal economy that dominates remote regions) (Smith, 2018, p. 11). Parliament's passing of the Reconciliation Law in September 2017, which grants impunity to public servants accused of corruption prior to 2011, was especially noteworthy for undermining the country's attempts to combat corruption as was the Parliament's decision to end the Truth and Dignity Commission in 2018. Added to the fact that the Constitutional Court, stipulated in the constitution, still remains to be appointed as well as recent amendments to the Law of Association (which now obligates non-governmental organisations to register with a national registry of institutions, a procedure adopted without civil society consultation) all mean that Tunisian politics is not without its problems, leading some to claim that the country is at a cross roads (Grewal, 2019) or even in a situation of 'democratic backsliding' (Fassihian, 2018). Youssef Chahad is now Tunisia's seventh Prime Minister since the revolution and has faced repeated calls to stand down, embroiled in an increasingly bitter battle with the new leader of Nidaa, Hafedh Essebi, the son of the President. Some now claim that Tunisia 'is in danger of developing into a hybrid system: part democratic, part authoritarian' (Gallien and Werenfels, 2019, p. 1).

While recent events paint an increasingly pessimistic view of Tunisian politics, there is still reason to be optimistic about Tunisia's future, not least the fact that 
Tunisian democracy has survived despite regional instability and serious security threats with municipal elections being held in 2018; Tunisia still has the potential, through parliamentary diplomacy, to play a unique role in IPIs as leading the way in terms of a socially acceptable brand of North African democracy which could be borrowed by other countries in the region. However, this potential is tempered by several realities.

While democracy appeared to be consolidated after 2014, recent surveys have indicated waning enthusiasm for democracy as a system. In Afrobarometer's survey of $2018,79 \%$ of respondents felt that the country was going in the wrong direction (up from $61 \%$ in 2015) with those expressing a preference for democracy dropping from $71 \%$ in 2015 to $46 \%$ in 2018 (Afrobarometer, 2019). Support for elections also declined, from $94 \%$ in 2013 to $90 \%$ in 2015 and then further down to $64 \%$ in 2018 . The declining support for the political system seemed exemplified in Spring 2018 when only 33.7\% of voters turned out for Tunisia's first municipal elections with the majority of those elected being independents (Fassihian, 2018).

The general unhappiness with politics and politicians seems clear. When asked in 2018, 96\% of respondents had never contacted an MP, while 95\% had never contacted a political party. To that effect, $81 \%$ indicated that they did not feel close to a party, whereas $55 \%$ felt that political parties created division and confusion in the country (Afrobarometer, 2019). When asked about the role of parliament, 36\% felt that the President ignored Parliament and did what he wanted and that most people felt MPs were involved in corruption with $34 \%$ saying some of them, $12 \%$ saying most of them and 17\% indicating all MPs were corrupt (Afrobarometer, 2019). When asked whether they approved how MPs had done their job in the previous 12 months, $22 \%$ strongly disapproved, $20 \%$ disapproved, while only $22 \%$ approved. Ultimately, the parties were seen as leading the country into stagnation, often quarrelling and satisfying no one. With a budget less than one-fourth of that given to the President's office, 'members of parliament consequently lack staff and office space. They rarely travel outside Tunis to meet constituents or influence the bills that their party leaders tell them to vote on. These and other weaknesses prevent the parliament from operating as an independent centre of power' (Fassihian, 2018, p. 3). In this way, political parties and MPs are often seen as part and parcel of the country's problems, not the centre of power for resolving them. Therefore, while popular support for democracy remains, the legitimacy of parliament is compromised and therefore its ability to imbue the population with democratic fervour. If anything, the turmoil surrounding the Reconciliation Law would suggest that the people are the driving force behind the normative transfer of democratic values as they were the actors who took to the streets to protest against policies which undermined the country's democratic credentials. 
Problematic is also the feeling that the Tunisian model could not be replicated in other countries. 'I believe that the success of national dialogue in Tunisia is rooted in forces that were deeply embedded in the soil of one country, particularly the absence of a politicised military and the presence of a massive domestic force, the General Union of Tunisian Workers .... This has no parallel in the Middle East. While Tunisia and its National Dialogue offer an inspiring example for the region, given such unique circumstances, it is unlikely to become a model that can be easily emulated elsewhere' (Brumberg, 2015, p. 56). Robbin's argues that Egyptians hate the players, Tunisians hate the game and this could indicate that even Tunisia's ability to export its democratic model is fragile and therefore so is the ability for its parliament to act as a norm entrepreneur in terms of a North African brand of democracy palatable to regional actors across the Arab world (Robbins, 2016).

Finally, Tunisia operates in forums that are not geared towards democratisation. Apart from the forums mentioned in terms of intra-regional assemblies like PAM and the PA-UfM (which have their own limitations as discussed previously), Pan-Arab parliamentary bodies place little emphasis on democracy promotion, as with the Arab Inter-Parliamentary Union (AIPU). Founded in 1974, AIPU is an Arab parliamentary organisation composed of parliamentary groups representing Arab Parliaments with the aim of strengthening joint Arab action though its shifting base is reflective of the political instability in the region, having moved from Damascus to Cairo with plans to relocate to Baghdad. While having a broad mandate, reference is made to enhance democratic concepts and values in Arab countries though the majority of its members are non-democratic regimes and its annual conferences are periodically preoccupied by calls to censor Israel. Therefore, while boding well for a more ethno-centric form of democracy promotion, the Tunisian Parliament's potential to act in a social constructivist manner as a norm entrepreneur for democracy promotion in the region is limited, both in terms of its role within Tunisia as a norm entrepreneur as well as an export model for other Arab states, whether on a bilateral basis or as a member of the regional IPIs within which it operates.

\section{Conclusion}

This article discusses the role of international parliamentary institutions in the democratisation process which began with such optimism after the Arab Spring. As indicated, only Tunisia can be considered to have transitioned to a functioning democracy and this reflects the fact that while outside actors may wish to influence outcomes, the transitioning society and state must have ownership of a process for it to be successful. For complex actors like the EU, their ability to influence normative change outside the EU is compromised by the fact that their 
actions may lack legitimacy and they are not consistent in pushing for normative change. They also lack the will to coerce change through reward or punishment while the targets in the receiving states may not have the connections within their societies to ensure that change is deep. Parliamentary bodies are even more compromised in the democratisation process because they often lack any coercive tools and are dealing with actors, national parliaments, which may have limited legitimacy back home. Therefore, the IPIs can be considered as highly limited actors in the area of democracy promotion and that the growth in democratic Arab parliaments does not indicate greater scope for optimism because these national parliaments often suffer from a legitimacy gap within their own countries which means that they are less likely to be able to lead by example.

\section{Conflict of interest}

The authors have no conflicts of interest to report.

\section{References}

Afrobarometer (2019) 'Afrobarometer Round 7, Survey in Tunisia 2018', accessed at http://afrobarometer.org/data/tunisia-round-7-data on 8 May 2019.

Alterman, J. (2019) 'A New Arab Spring?', Center for Strategic and International Studies Commentary, accessed at https://www.csis.org/analysis/new-arab-spring on 2 May 2019.

Beetham, D. (2006) Parliament and Democracy in the Twenty-first Century: A Guide to Good Practice, Switzerland, Inter-Parliamentary Union.

Brumberg, D. (2015) 'Could Tunisia’s National Dialogue Model Ever Be Replicated?', accessed at https://pomeps.org/wp-content/uploads/2015/11/POMEPS_BriefBooklet27 _Tunisia_Draft31.pdf on 30 May 2018.

Checkel, J. (1999) 'Norms, Institutions, and National Identity in Contemporary Europe', International Studies Quarterly, 43, 83-114.

Cofelice, A. (2016a) 'The Parliamentary Assembly of the Mediterranean and Its Contribution to Democracy Promotion and Crisis Management', Hague Journal of Diplomacy, 11, 292-310.

Cofelice, A. (2016b) 'Parliamentary Diplomacy and the Arab Spring: Evidence from the Parliamentary Assembly of the Mediterranean and the European Parliament', Mediterranean Quarterly, 27, 100-119.

Cofelice, A. and Stavridis, S. (2017) 'Mapping the Proliferation of Parliamentary Actors in the Mediterranean', IAI Working Papers 17/21, Istituto Affari Internazionali, Italy.

Fassihian, D. (2018) 'Democratic Backsliding in Tunisia', Freedom House Policy Brief, accessed at https://freedomhouse.org/report/special-reports/democratic-backsliding-tu nisia-case-renewed-international-attention on 4 May 2019. 
Fiott, D. (2015) 'The Diplomatic Role of the European Parliament's Parliamentary Groups', European Policy Analysis, Sweden, Swedish Institute for European Policy Studies.

Flockhart, T. (2005) Socializing Democratic Norms: The Role of International Organisations in the Construction of Europe, UK, Palgrave Macmillan.

Gallien, M. and Werenfels, I. (2019) 'Is Tunisia Really Democratising?', Stiftung Wissenschaft und Politik, Vol. 13, German Institute for International and Security Affairs, Germany.

Gomez Isa, F. and Munoz Nogal, E. (2016) EU Promotion of Deep Democracy in the Southern Mediterranean: A Missed Opportunity? European Commission, accessed at http://www.fp7-frame.eu/wp-content/uploads/2017/03/Deliverable-12.4.pdf on 13 December 2018.

Grewal, S. (2019) 'Tunisian Democracy at a Crossroads', Brookings Institute Briefing, accessed at https://www.brookings.edu/research/tunisian-democracy-at-a-crossroads/ on 8 May 2019.

Grugel, J. (2007) 'Democratization and Ideational Diffusion: Europe, Mercosur and Social Citizenship', Journal of Common Market Studies, 45, 43-68.

Hollis, R. (2012) 'No Friend of Democratization: Europe's Role in the Genesis of the 'Arab Spring', International Affairs, 88, 1.

Jonasson, A. (2013) The EU's Democracy Promotion and the Mediterranean Neighbours, UK, Routledge.

Jupille, J., Caporaso, J. A. and Checkel, J. T. (2003) 'Intergration Institutions: Rationalism, Constructivism, and the Study of the European Union', Comparative Political Studies, 36, 1/2.

Malmvig, H. (2004) 'Cooperation or Democratisation? The EU in the Eyes of the Others-Why Bother?', In Lucarelli, S. and Fioramoti, L. (eds) External Perceptions of the European Union as a Global Actor, UK, Routledge.

Marcussen, M. (2000) Ideas and Elites: The Social Construction of Economic and Monetary Union, Denmark, Aalborg University Press.

Pickard, D. (2014) 'Implementing Tunisia's New Constitution', IE Med Mediterranean Yearbook 2014, Spain, European Institute for the Mediterranean.

Risse, T. (2005) 'Social Constructivism and European Integration', In Weiner, A. and Thomas, D. (eds) European Integration Theory, UK, Oxford University Press.

Reinprecht, M. and Levin, H. (2015) 'Democratization through Public Diplomacy: An Analysis of the European Parliament's Reaction to the Arab Spring', USC Center on Public Diplomacy, USA, Figueroa Press.

Robbins, M. (2016) 'When It Comes to Democracy, Egyptians Hate the Player but Tunisian's Hate the Game', accessed at https://pomeps.org/wp-content/uploads/2016/ 03/POMEPS_Studies_18_Reflections_Web.pdf on 7 June 2018. 
Ross Smith, N. (2011) 'Europeanization through Socialization? The EU's Interaction with Civil Society Organizations in Armenia', Journal of Post-Soviet Democratization, 19, 385-404.

Schimmelfennig, F. (2015) 'The EU: Promoting Liberal-Democracy through Membership Conditionality'. In Flockhart, T. (ed.) Socializing Democratic Norms, London, Palgrave Macmillan.

Sezgin, Y. (2015) 'Why Is Tunisian Democracy Succeeding While the Turkish Model Is Failing?', accessed at https://pomeps.org/wp-content/uploads/2015/11/POMEPS_ BriefBooklet27_Tunisia_Draft31.pdf on 30 May 2018.

Smith, B. (2018) 'Tunisia 2018', House of Common Briefing Paper, accessed at: https:// researchbriefings.parliament.uk/ResearchBriefing/Summary/CBP-8342\#fullreport on 25 April 2019.

Stavridis, S. and Fernández Molina, I. (2013) 'El Parlamento Europeo y el Conflicto de Libia (2011): Una Tribuna Moral Eficiente?', Revista CIDOB D'Afers Internacionals, 101, 153-176.

Stavridis, S. and Irrera, D. (2015) The European Parliament and Its International Relations, UK, Routledge.

Volkel, J. (2017) 'Sidelined by Design: Egypt's Parliament in Transition', Journal of North African Studies, 22, 595-619.

Zamfir, G., Sgueo, G. and Dobreva, A. (2016) 'Promotion of Democracy and Peace in the World', Public Expectations and EU Policies Briefing, Strasbourg, European Parliamentary Research Service, European Parliament. 